\title{
Classroom Management through the Eyes of Elementary Teachers in Turkey: A Phenomenological Study
}

\author{
Sibel Akin ${ }^{1}$ \\ Middle East Technical University
}

\author{
Ali Yıldırım² \\ Middle East Technical University
}

\author{
A. Lin Goodwin ${ }^{3}$ \\ Teachers College-Columbia University
}

\begin{abstract}
This study aims to explore Turkish elementary teachers' (1) perceptions of classroom management, (2) classroom management problems they experience, (3) factors causing these problems, and (4) their classroom management practices. The study employed phenomenological research design in the qualitative tradition. The participants included 15 elementary teachers who were selected purposefully through maximum variation sampling. The data were collected through semi-structured interviews and analyzed through content analysis. Teachers reported classroom management problems in relation to physical environment, planning, time management, relationship management, and behavior management that have a connection to students, teachers, schools, classes, curricula, courses, and parents. Teachers described practices they employed to deal with these problems in relation to physical environment (e.g., seating arrangement), planning (e.g., developing effective lesson plans), time management (e.g., preparation for the class beforehand), relationship management (e.g., encouraging team spirit), and behavior management (e.g., assigning responsibilities to students). The sources of classroom management problems and potential solutions employed provide an insight into teachers' classroom management practices as well as implications for improving their classroom management skills.
\end{abstract}

Keywords

Classroom management $\bullet$ Constructivism $\bullet$ Elementary classrooms $\bullet$ Misbehaviors $\bullet$ Turkey $\bullet$ Phenomenology

\footnotetext{
* This study was presented at the American Educational Research Association Annual Meeting (AERA) in 2015.

1 Correspondence to: Sibel Akın, Departments of Educational Sciences, Middle East Technical University, Ankara Turkey. Email: siakin@metu.edu.tr

2 Departments of Educational Sciences, Middle East Technical University, Northern Cyprus Campus, Ankara Turkey. Email: aliy@metu.edu.tr

3 Teachers College, Columbia University - Departments of Curriculum and Teaching, New York, United States: Email: alg25@tc.columbia.edu

Citation: Akın, S., Yıldırım, A., \& Goodwin, A. L. (2016). Classroom management through the eyes of elementary teachers in Turkey: A phenomenological study. Educational Sciences: Theory \& Practice, 16, 771-797.
} 
Since classrooms are complex social and cultural settings with multiple events occurring simultaneously (Poole \& Evertson, 2013), classroom management is considered to be key to effective teaching. That is, teaching is a complex endeavor which requires teachers not only be effective in delivering the instruction but also maintaining the order (Rosas \& West, 2009). Research has supported the importance of classroom management for effective teaching and studies demonstrate that more effective teachers generally have better organized classrooms and fewer behavior problems (Evertson, 1985, 1989). Effective classroom management has been characterized as the process of establishing, maintaining, and restoring the classroom environment in an effective way for teaching and learning (Brophy, 1986). It refers to all actions taken by the teacher to create an effective classroom atmosphere where students could be highly engaged in lessons (Doyle, 1986; Romi, Lewis, \& Roache, 2013). This is, in return, expected to strongly influence the academic achievement of learners (Marzano \& Marzano, 2003; Wang, Heartel, \& Walberg, 1993) because it is widely documented that the actual time students spend on meaningful tasks is fundamental to their learning gains (Kunter, Baumert, \& Köller, 2007). However, classroom management has been ranked as one of the major problems that teachers face (Rosas \& West, 2009; Wubbels, 2011) because in regular classrooms, the available time is spent not only on learning activities, but also on non-curricular activities, organizational issues, or disciplinary problems (Kunter et al., 2007). As poor classroom management interferes with teaching and learning practices, it eventually becomes a major cause for teacher stress (Friedman, 2006), teacher burnout and job dissatisfaction (Garrahy, Cothran, \& Kulinna, 2005; Ingersoll, 2001) and results in teachers transferring to other schools or leaving the profession (Ingersoll \& Smith, 2003; Rosas \& West, 2009). It is also not surprising that classroom management is especially a high priority concern for beginning teachers (Doyle, 1975; Wubbels, 2011) given the strong possibility that failure to master the essential management skills causes discourage and disappointing experiences with students in class (Doyle, 1975).

Especially in today's world, the variety of stimuli in learning environments, the reality of social change leading to a diversity in the interests and needs of learners, and the heterogeneity in the background of the students, such as ethnicity, gender, ability, health, nationality, geographic region, social class, and age (Cushner, McClelland, \& Safford, 2009; Gay \& Howard, 2000) exacerbate the fact that classroom management has been a more serious concern for teachers than it has ever been before (Emmer \& Stough, 2001; Milner \& Tenore, 2010). Considering the fact that goals of education on the part of students have changed dramatically in the current era (Evertson \& Neal, 2006) and cognitive theories have been more influential on education, educational settings have stronger orientations towards student-centered learning environments over the past years. As a result, teachers are required to address the needs of their students who demonstrate an increasing demographic variety. Therefore, to maximize students' development by matching the school culture with student characteristics, 
teachers are expected to practice culturally responsive pedagogy. According to Ladson-Billings (1992), culturally responsive pedagogy is a term which is used to describe the kind of teaching in which student culture is used as the foundation for enabling students to understand themselves and others. This mainly implies that teachers should acknowledge the contexts, be responsive to the needs and interests of students, be responsible for the academic progress of all students, and integrate the elements of students' culture in their teaching. From a theoretical viewpoint, culturally responsive pedagogy has its foundations in social constructivism which encourages learner-centered education with a serious emphasis on responding to diverse characteristics and needs of all students as reality is constructed within a context through the terms, such as language, by which people perceive the reality (Au, 1998; Cummins, 1986; Schwandt, 1994). Consequently, empowerment of students with diverse backgrounds may lead to all students' successful participation in learning activities where teacher is a mediator.

Despite the serious call for culturally responsive pedagogy, research on multicultural education has tended to neglect the classroom management aspect (Weinstein, Tomlinson-Clarke, \& Curran, 2004). However, the context of classroom management practices has drawn attention as the background and settings may account for what students and teachers bring to the instructional process (Gay, 2002). The context, which might vary according to instructional goals, subject matter, grade, age, use of technology, socio-economic status of students, emotional and behavior disorders of students and so forth, has strong implications for classroom management, as well (Emmer \& Stough, 2001). Ultimately, bringing contextual factors to a conscious level is more likely to result in implementing equity initiatives in classroom, promoting freedom and justice for everyone, and making learning opportunities possible for all students (Gay, 2002; Weinstein, Curran, \& Tomlinson- Clarke, 2003).

Taking into consideration the close connection between the context and classroom management practices, the investigation of the way teachers understand and implement classroom management processes requires a close look into physical, cultural, and psychological aspects of classrooms. Turkish education has recently gone through a shift from behavioral to cognitive approaches in the curriculum and instruction. Despite this reform, such transformation in schooling practices has been challenging for teachers since Turkish education system still heavily depends on standardized testing. Besides, the social context of schools particularly with prevalence of unsupportive and unstandardized infrastructure, strict rules, and discipline do not leave much room for constructivist practices. Hence, it has been difficult for teachers to quit their behaviorism-oriented classroom practices and to switch to constructivist processes in classrooms. 
Along with the shift in the educational approaches, teachers are expected to adopt, in particular, a student-centered approach to classroom management (Çandar \& Şahin, 2013). That is, as the schools are having an increasingly diverse student population, teachers are encountering with a wider range of student behaviors and they are expected to respond more effectively to the misbehaviors (Mundschenk, Miner, \& Nastally, 2011). However, classroom management, indeed, has been one of the most debated issues in Turkish education system and it is mostly associated with discipline which has a lot to do with seeing the teacher as the authority of the class (Akar \& Yildirim, 2009). For instance, in Saban's (2004) study, it was seen that nearly two-thirds of the prospective elementary teachers perceived the role of teacher as the source of knowledge, one who transmits the knowledge, modifies students' behavior and one-third of them perceived their role as a guide in the learning process. Similarly, Akar, Tantekin-Erden, Tor, and Şahin (2010) found out that K-8 teachers had a tendency to practice traditional classroom management. On the other hand, in their study, Akar and Yildirim (2009) observed that teacher candidates underwent through a conceptual change in their metaphorical images about classroom management after experiencing a constructivist learning environment in a classroom management course. In their study, they found out that teacher candidates' descriptions of the metaphorical images about classroom management portrayed more a leading type of classroom management (e.g. orchestra conductor, football match, coach, theatre play, leader, boss, shepherd, and lion). This may imply that constructivist expectations and practices may create a change in conceptions of classroom management. Similarly, a study by Örücü (2012), conducted after the constructivist reform has taken place in Turkish education system, demonstrated that orchestra conducting, family management, ship, and factory management were the metaphors used by elementary teachers to reflect the idea of classroom management.

The classroom management problems most frequently experienced in Turkish schools have been reported to be talking out of turn, making noise, disturbing others, engaging in irrelevant activities, hyperactivity, making fun of other children, inattentiveness, attention deficiency, lack of motivation, chatting, daydreaming and not following instructions, complaining about classmates, nicknaming, and misusing the materials (Akkok, Askar, \& Sucuoglu, 1995; Altınel, 2006; Atici, 2007; Atici \& Merry, 2001; Cabaroğlu, 2012; Cabaroğlu \& Altınel, 2010; Demir, 2009; Güleç \& Balçik, 2011; Türnüklü \& Galton, 2001). The sources of misbehaviors might be attributed to families, teachers, students' characteristics, and environmental factors (Atici, 2007; Cabaroğlu, 2012; Güleç \& Balçik, 2011). With regards to classroom management, Akar et al. (2010) reported that K-8 teachers in Turkey mainly consider five themes, namely, the physical setting, planning the first days and motivation, rules and routines, coping with misbehaviors, and establishing teacher-parent cooperation. Moreover, individual talk about reason, talking with the disruptive student after the 
class, changing the group of the student, verbal and non-verbal warning, intonation, eye contact, hand clapping, monitoring, positive reinforcement, getting help from the school administrators or the psychological counselor, purposeful ignorance, assigning responsibilities, punishment, sending out, use of humour, providing instructions, reminding the class rules, asking questions, and reprimanding have been some of the classroom management practices that teachers mostly employ in schools in Turkey (Altınel, 2006; Atıc1, 2001; Atici, 2007; Cabaroğlu, 2012; Cabaroğlu \& Altınel, 2010; Çakmak, Kayabaşı, \& Ercan, 2008; Demir, 2009; Gokmenoglu, Eret, \& Kiraz, 2010; Güleç \& Alkış, 2004; Lozano \& Kizilaslan, 2013; Sarıtaş, 2006).

These research results show that while some of the practices employed by the teachers are more teacher-centered and having roots in behaviorism, teachers tend to integrate student-centered approach into their classroom management practices as well. On the other hand, it has been reported that even if it has been almost a decade since after the constructivist reform, the learning environment in the elementary classrooms is not yet truly aligned with constructivism (Baş, 2012). In their study, Çandar and Şahin (2013) also conclude that elementary teachers need to be more competent at classroom management if they are to establish a constructivist learning environment. Considering the long history of behaviorist orientation in the Turkish education system and the recent changes in the school curriculum toward constructivist teaching and learning process, it might be important to understand how teachers are shaping their classroom management practices and what they think about their effectiveness. In addition, the recent change in the school structure from $8+3$ to $4+4+4$ model resulting in the schooling of younger children in primary schools might also have some influence on teachers' classroom management behaviors. In their study, Cerit, Akgün, Yildız and Soysal (2014) concluded that schooling of younger children was the most outstanding problem of the new reform. Similarly, in the study conducted by Boz and Yildirım (2014), 55\% of the teachers reported that they experienced classroom management difficulties with the 60-65-month-old students in the class and that the age of those young students was the primary source of most problems leading to the classroom management difficulties. In addition, the 3-month adaptation period, in which teachers are expected to do preparation studies instead of implementing the formal curriculum, might have an impact on elementary teachers' classroom management experiences as they, thereby, encounter more difficulties with implementing the curriculum in the remaining school year especially with the effects of lack of revised curricula and textbooks (Boz \& Yildırım, 2014).

The literature does not provide us with a good understanding of teachers' experiences of classroom management issues since studies investigating teachers' perceptions of classroom management practices based on these changes and contextual challenges are only a few. In addition to this, a review study (Erdogan 
\& Kurt, 2015) on classroom management show that most studies focus on teacher profile and behaviors (40.7\%) and teachers' efficiency (24\%) while they are followed by classroom discipline problems $(20.3 \%)$ and classroom management strategies (14.8\%), which predominantly employ quantitative research designs. This qualitative study aims to investigate teachers' perceptions of classroom management from the standpoint of recent changes in the educational system as well as the contextual challenges teachers face in their classrooms, distinctly in a broader structure where metaphors, problems, factors, and practices are studied together. More specifically, the study seeks to answer the following research questions:

1. What are the perceptions of elementary teachers about classroom management?

2. What are the classroom management problems that elementary teachers encounter?

3. What are the underlying reasons of the classroom management problems from the perspectives of elementary teachers?

4. What are the practices of elementary teachers to deal with the classroom management problems?

\section{Method}

\section{Design}

This study is designed as a phenomenological qualitative inquiry. The term "qualitative" implies an emphasis on the meanings and processes that are not investigated through experiments or measured in terms of quantity, amount, or frequency (Denzin \& Lincoln, 2000). Concentrating on the deeper meanings individuals assigned to their lived experiences (Creswell, 2007; Marshall \& Rossman, 2006) toward classroom management, the qualitative phenomenological design in this study mainly relies on rich and detailed descriptions by participants' own words (Marshall \& Rossman, 2006). Phenomenology primarily rests on the assumption that human beings have some commonality or essence as they experience a phenomenon; thereby, phenomenologists seek to describe this shared structure (Creswell, 2007; Fraenkel \& Wallen, 2006; Marshall \& Rossman, 2006).

\section{Participants}

In this qualitative study, the participants of the study were selected purposefully through maximum variation sampling (Patton, 1990). This allowed including a wide range of variation on certain dimensions (Patton, 1990) in participating teachers such as teaching different grade levels and the university graduated, which might influence teachers' 
classroom management perceptions. Although sample size is usually around 7-10 for phenomenological studies (Yıldırım \& Şimşek, 2011), this study involved 15 female elementary teachers to ensure the data saturation as the weightier concerns regarding the number of participants in qualitative research mainly relate to data saturation. The participating teachers (Teacher-A, -B, -C, -D, -E, -F, -G, -H, -I, -J, -K, -L, -M, -N, -O) graduated from education faculties of different universities and represent different class levels: 4 teaching 1st grade, 3 teaching 2nd grade, 3 teaching 3rd grade, and 5 teaching 4 th grade, holding only undergraduate degree, and working in public elementary schools in Ankara, Turkey. Their teaching experience ranged from 3 to 18 years. All teachers had taken a classroom management course during their initial teacher preparation. The number of the students they have in their classrooms ranged from 20 to 43.

\section{Data Collection Instrument}

To gather data in the subjects' own words and uncover the participants' perspectives on a phenomenon, qualitative researchers depend to a large extent on in-depth interviewing (Bogdan \& Biklen, 2007; Marshall \& Rossman, 2006). The primary advantage of interviewing is that it focuses on the deep meanings assuming that they guide the actions (Marshall \& Rossman, 2006). Accordingly, the data were collected through semi-structured, face-to-face, and in-depth interviews. This approach allows for the specification of the questions in advance, offers the interviewer considerable flexibility to ask for a range of topics and offers the subject a chance to shape the content of the interview. In addition, it allows for getting somewhat systematic and comparable data across respondents through an interview form as well as allowing for addressing the depths of the phenomenon (Bogdan \& Biklen, 2007; Patton, 1990). The interview schedule in this study was developed by the researchers on the basis of the review of related literature and the research questions of the study. It was developed in Turkish and consisted of open-ended questions to elicit in-depth information for the purpose of the study (e.g., When you consider your experience as a teacher with students, what comes to your mind in relation to "classroom management" concept?, What kind of a classroom management system do you have as a teacher?).

Having taken the opinions of three experts to prevent ambiguity and to establish connection between the purpose of research and the questions in the interview, the instrument was revised on the basis of given feedback. Then, it was piloted with three elementary teachers to assure the clarity, relevance, and effectiveness of the questions as well as to assess the flow of the questions and timing.

\section{Data Analysis}

Each interview took nearly 30 to 45 minutes and was audio-recorded. In qualitative studies, data analysis involves breaking the data into manageable parts, searching for 
patterns, and synthesizing them (Bogdan \& Biklen, 2007). Correspondingly, content analysis was used to analyze the data. To this end, all the audio-recorded interviews were first transcribed verbatim by using a computer-based word processing program, and then with the help of the initial concepts from the relevant literature and the research questions as guidelines, each transcription was coded to derive relevant themes. As the initial categories were derived and themes were shaped around the emerging codes, they were subjected to refinement until the write-up stage. Finally, alongside the reporting of the findings and interpretations, all the themes related to the research questions were described and exemplified in detail through quotations which were translated from Turkish to English. To ensure that all the meanings and nuances are well-reflected in the translations, an expert was asked to provide her opinions on the translated quotations by comparing them with the original expressions.

\section{Trustworthiness}

To ensure rigor in qualitative research, trustworthiness can be assessed through the criteria of credibility, transferability, dependability, and confirmability, all of which can be satisfied through several strategies (Marshall \& Rossman, 2006). In order to address trustworthiness in this study, firstly, credibility was assured through the following strategies: consulting experts after developing the interview schedules and making necessary revisions, piloting the interview schedules before the actual data collection, in-depth and thorough data collection with the use of open-ended interview questions, member checks through checking both the data and the interpretations with the selected participants, prolonged engagement with data through spending sufficient time for each interview and also having an iterative data coding process, persistent observation by a thorough data collection, detailed transcriptions, and researchers' notes, and finally peer debriefing by having conceptual discussions with another researcher who has expertise in qualitative research. Second, transferability was addressed through purposive selection of the participants with the use of maximum variation sampling and also through thick description by describing the context, relevant characteristics of the participants, data collection, analysis, and results. Finally, for dependability and confirmability, audit trail was employed to check the consistency and objectivity of the results through the constant feedback provided by a qualitative researcher in the research process and at the end.

\section{Results}

\section{Positive and Negative Connotations about Classroom Management}

The results revealed that teachers had both positive and negative associations with classroom management. On the positive side, teachers perceived classroom 
management not as a way of strict discipline, but as assigning responsibilities to students, developing a sense of belonging on the part of the students, establishing rules together, enabling students to enjoy the school and the class, having a two-way communication in the class, recognizing students' needs and interests and respecting their individual differences, and also encouraging students to respect each other. To illustrate, Teacher A said that:

I don't necessarily think of discipline when I think about classroom management. My classroom management is mainly based on assigning responsibilities to students. Each student is a unique individual and it is more important for me that $\mathrm{s} /$ he feels at home in the class, joins the process of establishing the rules, etc. I have 25 students and each of them has their own roles in the class. I always do so.

On the negative side, classroom management was perceived to be directly connected to the problems and also the skills for solving those problems, as Teacher B expressed that:

When someone mentions classroom management, it makes me to think about the problems, the possible problems that might occur in the classroom. What kind of problems I may have... Problems and the ability of problem solving... The problems are not necessarily only about the students, it could be any problem...

\section{Metaphorical Images}

Teachers' perceptions and experiences revealed different metaphors in relation to not only classroom management itself but also their own and their students' positions in the context of classroom management.

Most teachers resembled classroom management to an "orchestra," particularly reflecting the idea of acting in harmony. From her own words, Teacher A asserted that:

It resembles to an orchestra... Yes, the teacher is coordinating and leading the class. Certainly, there are a lot of different voices in the class. In my opinion, classroom management is the ability of putting these voices in harmony.

A number of teachers, in a similar manner, perceived the classroom management as a "game" given that it allows for freedom and happiness as well as it requires the establishment of rules. Some teachers thought that classroom management is similar to "music" in the sense of being a tool to create a positive atmosphere. A few teachers perceived the classroom management as a way of "self-expression and communication." Finally, one teacher resembled classroom management to the act of "reflecting," pointing out that whatever happening in the classroom is two-way: reflected from teacher to students and from students to teacher. 
Most teachers viewed the teacher in the context of classroom management as the "coordinator of the orchestra or maestro" in terms of assigning responsibilities to students, coordinating them, and being the leader of the group who creates the harmony. Other metaphors associated with the teacher in the context of classroom management were the "motion-sensitive camera" in terms of immediately responding to every child, the "mirror" in terms of being a primary means for the mirror images (students), and the "Earth" in terms of observing all different stars (students). To illustrate, Teacher E said that:

Myself, as a teacher... You know, there are some motion-sensitive cameras which move around according to the surrounding motions... Just like a motion-sensitive camera, I have to move around to be aware of all students and to respond them quickly.

Teachers metaphorically associated the students mostly with "stage actors," "theatre players," "ant swarm," "instruments for an orchestra," "songs," "mirror reflection of teachers," "songs," "stars" or "snowflakes," and "artists playing different instruments." within the context of classroom management. The common point reflected in most of these metaphors was students' having unique individual characteristics, different responsibilities or roles in the class, as Teacher $\mathrm{H}$ and Teacher $\mathrm{K}$ clearly expressed that:

...To me, they all look like different theatre players. Each of them is different, each of them has her/his responsibilities. All of them have their own roles in the class, they are all different individuals. (Teacher $\mathrm{H}$ )

They are just similar to the stars or snowflakes. None of the stars look like each other, neither do students. They are all different from each other. As a result, my approach to every single one is also different. They have their own individual characteristics, so you cannot expect that the same approach fits to everyone. (Teacher K)

\section{Perceptions of Elementary Teachers about Classroom Management Problems}

Classroom management problems teachers experienced were mainly related to planning, time-management, relations with students, and behavior management.

Planning-related handicaps. Regarding the first category, planning related handicaps mostly centered on the curriculum. Teachers mentioned that they were not able to catch up with the curriculum due to the insufficient course hour. They also related their concerns to the heavy number of objectives in curricula, the inflexibility of the centralized curriculum to different settings, and yearly unit plans' taking too much time. For example; Teacher J mentioned that:

The curricula are not developed by considering those different regions which have all different characteristics. As a result, the curricula that we have been implementing are mostly applicable to the urban areas or big cities but we definitely need to modify them 
according to our settings because what they offer in the curricula are not always applicable to our settings or to the opportunities that we have. I used to work in various settings before and this is something that I can say for sure.

Time management-related handicaps. Being connected to both curriculum and students, teachers addressed the inappropriateness of the curriculum for students' level of readiness as well. Either on the part of the students or themselves, teachers mentioned that not getting prepared for the lesson beforehand was another cause of those planprogram related handicaps. Insufficient course hour and number of objectives in the curricula perceived to be time management-related handicaps, as well. On the other hand, other time management-related handicaps included operating double shift schooling which splits the school day into either morning or afternoon schooling and causes to less instructional time as a result of students' needs such as sleep or leads to narrow attention span in late afternoon courses. In this regard, Teacher $G$ pointed out that:

...Because our school operates full-day schooling, it causes to many difficulties. Classroom management becomes very difficult because these are small kids and it gets harder to attract their attention in those late afternoon classes. As a result of that, time management gets negatively affected also in the other classes. I believe that it causes to similar consequences in the morning groups, as well. Kids are coming to school without sleeping or eating enough. If otherwise, they are coming late to the first class and distracting the attention of other kids, which directly causes loss of time since you will need to get started from the beginning and try to attract the attention.

Similarly, having less time for the course objectives due to dealing with student misbehaviors emerged as one of those time management-related handicaps.

Relationship management-related handicaps. Regarding the third category, it was seen that relationship management-related handicaps focused on both the relationships among students themselves and also the relationship between the teacher and the students. In this regard, fights and complaints of students, jealousy among students for teacher's care, and difficulty in ensuring an equal distance in relationships with all students were the relationship management-related handicaps.

Behavior management-related handicaps. Finally, behavior management-related handicaps mainly related to taking control of students with behavioral disorders or learning disabilities and energetic students. Teachers expressed that they were not able to spend enough time with managing the behaviors of those students and rest of the students at the same time. More specifically, Teacher B said that:

I have two inclusive students in my class as most schools and classes have. Obviously, they are not at the same learning pace with others. Typically, teachers prepare another plan for these kids around another set of objectives. However, despite having just 20 students, I personally sometimes feel like I am unable to spend enough time with them. You cannot 
just leave the rest of the class on their own and care only about those students because these are small kids and the class easily starts to get in a chaos.

The difficulty of dealing with such a variation also appeared in managing the misbehaviors of the students who were transferred from another school or another class during the semester because compared to other students, those students mostly were not at the same place in terms of the achieved learning objectives. Similarly, dealing with the difference and variety in students' level of readiness was perceived to be a handicap for behavior management. Finally, students' disobedience to the rules and the difficulty in correcting misbehaviors learned from parents were other common behavior management-related handicaps as perceived by teachers.

\section{Perceptions of Elementary Teachers about the Factors Causing Classroom Ma- nagement Problems}

The results portrayed that the factors being likely to cause classroom management problems were related to students, teachers, school, classroom, curriculum, course, and parents.

Student-related factors. Student-related factors partially pointed to the background characteristics that not all students but some of them brought with themselves into the class such as not having initial early childhood education, speaking Turkish as a second language, having single parents, changing several elementary teachers, school transfers, migration and adaptation to a new class setting, and inclusive students' special needs. For instance; Teacher B, Teacher C, Teacher F, and Teacher N expressed that:

...This area has a high rate of migration and cultural variety. This becomes a source of difficulty for managing the classroom. What else... Non-attendance at school also negatively affects the classroom management. Because of the area where our school is located, we have students who start school in the middle of the first semester and leave the school in middle of the second semester. This is a problem for classroom management. Since these students are working on the farms to support their parents, they are not attending at school regularly. Ultimately, this disrupts all those previously established classroom practices. Therefore, I can confidently say that migration or, similarly, the transfer of students from other schools or classes becomes a problem for classroom management. (Teacher B)

Especially when I was working in the east part of Turkey, leave those formal objectives alone, I experienced that students were not even able to speak Turkish and achieve the informal learnings, which dramatically affects the classroom management. (Teacher C)

Those students who did not have early childhood education before the elementary school do not easily get separated from their parents and get used to school. Likewise, such students never actively attend the class for an entire period of 40 minutes. (Teacher F) 
There are some kids who have single parents as a consequence of death or divorce. These kids require an extra effort on the part of the teacher and inevitably we are coming across with difficulties in managing the classroom. (Teacher $\mathrm{N}$ )

In addition, there were more common factors related to the students' academic characteristics such as low level of readiness and the difference in the readiness of students, students' inattentiveness and low interest toward the course, narrow attention span, not getting prepared for the course beforehand, non-attendance at school, low schooling age, and coming late especially the first class of the day. Talking about the low schooling age, Teacher F stressed that:

Teaching especially the first graders, this year I realized that I do not have enough knowledge of children's games. This year, for the first time in my teaching experience, I am teaching students who are at the age of 5 or 5.5. Attracting their attention, encouraging them to attend the course, using different activities are all crucial. However, after the recent educational reform of $4+4+4 \ldots$ You know... The lower the schooling age, the lower the students' level of readiness. Besides, it caused to the fact that we have students of different ages in the class, such as 5, 5.5, 6, 6.5, 7, 7.5. I had a lot of difficulties. Even their games and interests just vary over those different ages. And being small kids, they have problems with the abstract concepts.

Finally, the unmet needs such as self-care, sleep, food and also certain developmental characteristics such as being more disobedient due to the puberty or the change in interests in the late elementary school years were found to be important student-related factors.

Teacher-related factors. Teacher-related factors were connected to teachers' personal traits (e.g., age, personality, educational beliefs, life) or their educational/ professional background characteristics such as their initial teacher education in terms of being more oriented towards theory acquisition but less to practice in the classroom management course, not learning the essential knowledge and skills for classroom management, and not being prepared for teaching children with behavioral disorders during or after the initial teacher education, as Teacher A pointed out that:

...The classroom management course that I had during my initial teacher preparation was just too theoretical. We hardly ever practiced what we learned. Our professor used to lecture all the time. I realized this deficit way of learning when I started the actual teaching. Another thing... We did not have an education about those inclusive students either during or after the initial teacher education although it is well-known that there is a couple of inclusive students in almost all classes. This is a very important issue both for those kids and also for us as teachers I believe.

Except these educational/professional background characteristics, having few teaching experience, having negative attitudes towards the profession, not getting 
prepared for the course, multilingual incompetency, and inconsistency between the teacher behaviors and the decisions appeared as more individual factors. Finally, teacher attrition in terms of teacher migration was also found to be another important teacher-related factor since it is likely to lead to students' orientation problem to new teachers and also lead to more crowded classrooms considering that less number of teachers would be present in schools. In this respect, Teacher L expressed that:

...I used to work in the east part of Turkey before I started to work at this school. I can truly say that most teachers do not want to keep living in the east. Therefore, there is always teacher mobility and students are changing teachers for many times. Teachers try to move to the west areas of Turkey as soon as possible. As a result, those students are either left with no teacher or a different one, which eventually causes adaptation problems and becomes an impediment to classroom management.

School-related factors. As another category, some of the school-related factors were found to be related to administrative climate of the schools. In that sense, disciplinary attitude of school administrators, their communication styles with students as well as parents, their lack of collaboration with teachers, the inconsistency between school and class atmosphere, and negative school environment along with lack of rules and encouraging practices were the factors leading to classroom management problems, as Teacher $\mathrm{C}$ asserted that:

...The attitude of school administration is also very important. Neither should they be very disciplined nor laid back. When it is too disciplined, it causes communication problems between the school and the students or the parents. Not surprisingly, it also creates a tension in the classroom. I completely believe that school administrations should cooperate and be in line with teachers and their practices. Nothing can be truly achieved unless they support the teachers. Teachers should be confident in that they are receiving enough support.

School-related factors also centered on the school environment such as lack of security precautions in and around the school, school's being located in a seasonal migration-receiving area, inadequate infrastructure of the school, school environment itself as a cause of bad habits, and operating double shift schooling. For instance; Teacher B mentioned that:

Students like physical education course very much but as we do not have adequate physical infrastructure such as having a gym, I mostly feel that I have to replace this course with other courses especially in winter time. However, when this becomes the case, they lose their motivation towards those other courses and this makes classroom management harder.

Class-related factors. Considering the class-related factors, it was understood that inadequate infrastructure of classrooms (e.g., physical size, seating arrangement, bulletin boards, desks), physical location of the classrooms especially in terms of 
being in a noisy location (e.g., near the kindergarten or secondary school classes), uncleanness of the classrooms and having poor heat and light, and sharing the classroom and the class materials with another class due to double shift schooling (e.g., sharing bulletin boards due to morning/afternoon classroom shift) were the factors more associated with physical conditions of the classrooms. On the other hand, class size, grade level, different needs of students in multilevel classes, and negative class atmosphere were the other class-related factors which were based more on class dynamics rather than physical conditions of the classrooms. Teacher $\mathrm{H}$, Teacher I, Teacher M, and Teacher O mentioned that:

We should not think about just the east part of Turkey. I used to work in the rural areas of this big city, as well. There are multigrade classes here, too. The classroom management in those classes cannot compare to the one in regular classes. You have to have strong classroom management skills and respond to the both groups during the class: the group being actively taught by the teacher and the group assigned some work by the teacher to study on their own. (Teacher $\mathrm{H}$ )

If we want our students to have a better education, I, as a teacher, strongly believe that class size should be around 20 to 25. Crowded classrooms... A big reason of poor classroom management. (Teacher I)

Our classroom is just opposite to the bathroom and also there is a kindergarten next to our class. As those are smaller kids, we always suffer from noise. The physical location of the classes matters a lot. (Teacher M)

Once you have double shift... For example; let's say that you are hanging something on the bulletin board now but it just disappears when the second party uses the same classroom. In other words, you are not able to fully take control of the classroom. (Teacher O)

Curriculum-related factors. The results revealed that curriculum-related factors leading to classroom management problems were disproportionate number of objectives with regards to the given amount of course hour, inappropriate sequence of the objectives, inappropriateness of the objectives to the students' level of readiness, and the inflexibility of the centralized curriculum to different settings. To illustrate, Teacher D explained that:

I think the course hours are not sufficient. Therefore, students are not able to acquire well enough the objectives. The curriculum needs to be simplified considering the developmental levels of the students. They should be able to learn every single thing by doing but as we have time constraints, we cannot practice that enough. There are too many objectives, some of which are not either appropriate for the kids, at all. Besides, hours of some of the courses were shortened. As a result, the suggested course hours absolutely conflict with the suggested activities. 
In addition, number of courses, the lack of materials to support the implementation of learner-centered curriculum, and curriculum's irresponsiveness to lowered schooling age were the other curricular factors triggering classroom management problems. For instance; Teacher A mentioned that:

The current curricula are learner-centered; thereby, they suggest variety of activities. However, we do not have adequate infrastructure for them. For instance; we cannot use our labs as much as it is encouraged in the curricula. What else... Every class must be technologically well equipped but not every classroom has such infrastructure.

Course-related and parent-related factors. Course-related factors could either be associated with students such as their low interest toward the course and the importance attached to the course by them or the course itself such as the difficulty level of the topic and the abstract courses in nature.

Regarding the parent-related factors, it was seen that the background characteristics of parents such as low socio-economic status and migration or the educational impacts of parents on their children such as the misbehaviors learned from them, the misbeliefs developed by them, their lack of attention towards school, valuing the teachers, and collaboration with the teacher, not attending adult education seminars, and the inconsistency between school and home learnings were likely to trigger classroom management problems. To illustrate, Teacher G said that:

Parents are an important factor. They are even the most important of all because education starts at home and then continues at school. Whatever learned at home is immediately transferred to the school. For instance; unintentional informal learnings such as swearing... ...If the parents do not care about the education of their children, the child becomes less interested in the school. I have seen such parents that they even do not value the teacher. As such, the student is less likely to transfer what $\mathrm{s} /$ he learned at school to the home setting.

\section{Perceptions of Elementary Teachers about the Classroom Management Practices}

The results demonstrated that elementary teachers employed five groups of practices to deal with the classroom management problems: (1) physical environment practices, (2) planning practices, (3) time management practices, (4) relationship management practices, and (5) behavior management practices.

Physical environment practices. To start with the first category, teachers' physical environment practices to deal with classroom management problems mainly focused on the physically orderliness of the classroom such as seating arrangement, orderliness of desks, visuals, materials, and bulletin boards as well as their content, and cleanness of the classroom. For example; Teacher F expressed that: 
I do not like the fact that students generally sit in rows in the classroom. I do not allow only for one fixed type of seating, rather, we usually arrange the seating during the breaks depending on the activity that we will do. By doing so, everyone becomes academically more engaged which eventually positively affects the classroom management.

Except the classroom order, teachers were also concerned about the physical appearance of students (e.g. cleanness), assigning responsibilities to students for a clean classroom, and asking for parents' help for necessary physical conditions. Finally, adjusting an optimum heat and using materials to draw attention were also found to be important physical environment-related practices.

Planning practices. Teachers' planning practices resulted in two sub-themes: practices before the course and practices during the course. The practices that teachers did before the course were mostly related to curricular preparations. These included the activities they employed mostly by themselves such as developing a daily plan, checking the teacher's guide, getting prepared for the topic beforehand, and making modifications in the curriculum with respect to the children's level of readiness and needs, the infrastructure of the school, and the parents' expectations. Accordingly, Teacher L asserted that:

Unless you develop a plan before the class, however experienced you might be, classroom management gets more difficult. Mostly what I do before the class is that I review the topic and also check the guide book. It is important to decide if they are appropriate for the developmental level of the students, materials are prepared and adequate. If I am to make a modification, I generally make sure that I do it before the class.

On the other hand, they also employed some practices that point to the consideration of students such as providing supplementary resources to them and giving clear instructions/homework before next class and also to the consideration of colleagues such as collaborating with them on weekly plans and preparing yearly unit plans at the beginning of the semester, as Teacher $\mathrm{C}$ said that:

We have our group of elementary teachers at school who teaches the same grade. At the very beginning of the each semester, we come together and develop a yearly plan. Besides, every week we share with each other what topic we are currently engaged in, what kind of activities we do, what kind of difficulties we have.

Except these practices employed before the course, the practices that teachers employed during the course were using multiple stimuli, materials, and activities to draw attention, doing learner-centered activities, and encouraging team work and collaboration with others, all of which target the active involvement of students in the course. More specifically, Teacher $\mathrm{O}$ expressed that: 
These are small kids. Their attention is distracted very easily. You always need to integrate something interesting to the course. I usually enrich the course with visual materials so that they become more active during the course. For sure, that makes the classroom more manageable.

Time management practices. Time-management practices were found as focusing on curricular preparations such as preparing daily plans, preparing yearly unit plans at the beginning of semester and considering time-objectives proportion, getting prepared for the topic beforehand, and choosing the activities on the basis of difficulty level and time. Another important practice emerged as encouraging scaffolding among students.

Relationship management practices. Teachers had different relationship management practices either for establishing the classroom management system or maintaining the classroom management system. Regarding the former, teachers were being sincere and close to students, creating a comfortable environment for communication, establishing a democratic class atmosphere, encouraging respect for others, encouraging team spirit, respecting students' ideas, not comparing students but encouraging collaboration, friendship and monitoring the relationship patterns among them, not applying strict disciplining, preventing the complaints, and developing students' conflict management skills. For example; Teacher A said that:

It is important students believe that they can comfortably express themselves in the class. It is also important that they do not feel shy because of you as the teacher or other kids in the class. I try to be open and warm to them so that they know that they can share everything with me. But sometimes we have the problem of complaints. Complaining about others... You know they are not adults. At those times, I try to instill the idea of being a family, a team. I never compare them, as long as you keep encouraging the team spirit, their relationships automatically get better.

On the other hand, considering the maintenance of the classroom management system, it was seen that discussing the problems together, making decisions with the class, changing seating of students for enabling them to develop good relations with others, using positive and negative reinforcement, rewarding, and giving verbal advice and guiding were the practices teachers did as part of their classroom management.

Behavior management practices. Finally, behavior management practices also resulted in two sub-themes: establishing the classroom management system and maintaining the classroom management system. Regarding the first one, it was seen that teachers were establishing the rules at the beginning of the semester together with students, discussing the rationale of the rules, displaying the rules, doing class evaluation about obeying rules, establishing a warm climate based on love and trust, developing a sense of belonging, encouraging respect for others, teaching etiquette, 
being polite, preventing offensive behaviors, being against physical and verbal violence, taking students' interests and level of readiness into account, attending to in-service trainings, and collaborating with parents and colleagues (e.g., other elementary teachers, school counselor, school administration) to deal with classroom management problems. In this regard, Teacher I expressed that:

As a teacher, I favor the idea of setting the class rules together with students. We usually discuss the rationale of the rules or the reason why we need that rule... As long as they participate in rule setting process, they become more aware of their actions and behaviors because they feel more a part of the class.

On the other hand, to maintain their classroom management system, teachers were doing interesting course activities to draw students' attention and keeping them engaged with the course through giving tasks, not only assigning responsibilities but also giving students right to select their responsibilities, using punishment, rewarding, positive and negative reinforcement, intonation, warning, gestures, encouraging the team spirit, leaving the student free to let him/her realize the undesired behavior, monitoring students with behavioral disorders and normalization of them in the class, spending extra time with transferred or inclusive students, encouraging parent involvement, and collaborating with school administration.

\section{Discussion}

This study aimed to investigate the phenomenon of classroom management in Turkish elementary education context with a focus on elementary teachers' perceptions about classroom management, classroom management problems, factors causing these problems and the practices they employ to deal with those problems. The motivation underlying this purpose was to understand if their beliefs and classroom management orientations are in line with the constructivist learning environments which have been promoted since after Turkish education system underwent certain reform initiatives in 2005 .

In the current era, education, as well as the other fields, is experiencing radical changes in philosophy about teaching and learning (Dollard, Christensen, Colucci, \& Epanchin, 1996). Teachers are expected to not solely foster the cognitive development of their students but also consider their affective development, organize effective learning and teaching environments, and employ contemporary classroom management approaches. Being one of those approaches, constructivist classroom management underlines teachers' knowledge and awareness about students' different learning styles, individual differences, and needs (Randolph \& Evertson, 1994; Weinstein, Woolfolk, Dittmeier, \& Shanker, 1994). According to Villegas and Lucas (2002), children are more likely to get prepared to fulfill their roles when 
they receive constructivist education rather than an education that is based on conventional thinking. Dollard, Christensen, Colucci, and Epanchin (1996) argue that this is because overcontrolled environments intimidate students and impede student learning. Besides, students and teachers feel disconnected from each other and learning is disrupted due to the lack of meaningful dialogue and productive relationships. On the other hand, constructive approach is child-centered and teachers share control and leadership with their students (Garrett, 2008). In addition, it is more conducive to build positive teacher-student relationships which are characterized by trust, respect, and understanding and which also give important credits to the child's needs and interests. In such an environment, students are less likely to worry about their emotional, physical, and academic safety in the classroom because the focus of dialogue depends on shared understandings and investment in collaborative decision making (Dollard et al., 1996). Students share responsibilities in the classroom and rules are developed by both the teacher and the students (Garrett, 2008). Providing students with the opportunity to participate in classroom management positively influences the student behaviors (Voakley, 1975). Partnership of the teacher and the student ultimately creates space for autonomy and results in the fact that the student constructs the knowledge by his or her actions and experiences (Beasley, 1996).

The findings of the study show that elementary teachers use physical environment practices, planning- practices, time management practices, relationship management practices, and behavior management practices to establish and maintain an effective classroom management system. The findings also indicate that they mostly seem to adjust their classroom management orientations towards constructivism by considering the students at the very center of their choice of classroom management practices. To this end, they assign responsibilities to the students or give them a choice to select their responsibilities, consider their level of readiness and needs and make modifications in the curriculum, use multiple stimuli, materials, and activities to draw their attention, choose the activities on the basis of their difficulty levels for students, use learner-centered activities, encourage collaboration, scaffolding, and team spirit, create a warm and democratic learning environment, respect students' ideas, build relationships with them based on love and trust, and make them active in the decision making processes about the class. Similarly, it is understood that teachers consider it important to respond to the needs of students with any special needs such as transferred or inclusive students. Drawing upon these, it can be argued that after the reform attempts in the Turkish education system and particularly in the philosophy of the system of education, teachers mostly dissociate themselves from teacher-centered classroom management practices. Similarly, through elementary teachers' self-reportings, Yaşar (2008) concluded that Turkish elementary teachers use student-centered classroom management approaches more than teacher-centered approaches. On the other hand, the findings of this study also indicate that the existence of some disparities are still 
noticeable and may originate from the behaviorist practices which still have roots in Turkish education system. To illustrate, it is evident from the data that teachers still employ some practices which are rooted in behaviorism such as positive or negative reinforcement and punishment. Besides, they use extrinsic rewards which are widely used mechanisms in teacher-centered classrooms (Garrett, 2008).

Regarding the perceptions of teachers about classroom management, the findings of the study demonstrate that classroom management is not perceived as a way of strictly controlling the students; rather teachers attribute quite positive meanings to it. The conceptions of teachers about classroom management are mostly characterized by collaborating with students while making several decisions, considering their needs and interests, assigning responsibilities to them, creating a sense of belonging, and respecting them. Especially considering the fact that elementary school students are young and in need of more care, custody, and love compared to other stages of schooling process, this finding indicates that teachers' beliefs comply with the idea of responding to the needs of learners and also that teachers perceive students' affective development as important as their cognitive development. Therefore, they seem to create positive learning environments mostly based on dialogue and effective communication.

The findings further demonstrate that elementary teachers face with planningrelated handicaps, time-management related handicaps, relationship managementrelated handicaps, and behavior management-related handicaps in relation to classroom management. On the other hand, the factors causing these problems appear as student-related, teacher-related, school-related, class-related, curriculum-related, course-related, and parent-related. These factors might be significant for improving the relevant circumstances for teachers to help them manage their classrooms more effectively. Among all, some of the factors are more context-specific than others. For instance, it is known that especially young elementary teachers in Turkey mostly start their teaching career in rural areas where not only do they work in high-need schools but also they mostly have a communication problem due to not being able to communicate in local languages. Therefore, it might be suggested that such courses should be integrated into the initial teacher education program to develop teachers' multilingual competence. Similarly, such areas usually suffer from teacher attrition as teachers want to work in better conditions and, thereby, tend to move to schools in other areas. Hence, the conditions of the schools in rural areas should be improved to prevent teacher mobility or attrition which are likely to push students in more crowded classes because of the less number of available teachers in those schools. However, large class size is perceived by teachers as a factor which complicates the classroom management process. Therefore, it might be implied that teachers call for better class size policies, as well, which should aim to decrease the large class sizes that might be observed not only in those schools but also in urban schools. Besides, teachers should 
be provided with more flexibility in the implementation of the centralized school curriculum to be able to respond to the characteristics of those different regions and settings and more effectively manage their classrooms. Lastly, as evident from the interviews, students in those poor areas are more likely to work and financially support their families. Especially during certain periods which are critical for definite types of work (e.g., farms), those students are less likely to regularly attend at the school over the semester. This finding might suggest implications for policymakers to ensure the regular attendance of all students at schools through certain policies and actions.

Another important factor causing difficulties in classroom management is reported to be the low schooling age. Although $4+4+4$ reform enterprises in Turkish education system recently introduced a lower schooling age, it is apparent from the data that this has a negative impact on teachers' classroom management system. Hence, it might be necessary to support teachers with in-service trainings about how to respond those younger children and create an effective classroom management system. Similarly, the initial teacher preparation program should be revised to allow teacher candidates to develop necessary knowledge and skills to be able to respond younger children as the program has not been updated yet despite the recent changes that took place in the education system of Turkey. In addition, early childhood education should be strengthened and encouraged more to prepare all children for elementary education since it is seen that early childhood education emerges as a factor that has a positive influence on classroom management by allowing young children to get better prepared for further schooling. Moreover, parent-teacher collaboration should be reinforced to support elementary teachers in managing their classrooms. Finally, it can be also argued that the initial teacher education program should better prepare the teacher candidates for managing the multigrade classes which are mostly prevalent in the rural areas and require a well-established classroom management system. To this end, it might be suggested that relevant courses offered during the initial teacher education program should be redesigned and strengthened. Besides, teacher candidates should be provided with more opportunities to practice their classroom management skills and interpret their new knowledge both in regular and multigrade classes in elementary schools during their teacher preparation program. As Garrahy, Cothran, and Kulinna (2005) argue, teachers usually have a stronger belief in their wisdom of practice. In this regard, it can be suggested to leave much room for progressive, well-designed observations and practicum experiences both in the classroom management course and during the field experiences as almost all teachers regardless of the university they graduated contend that their four-year teacher preparation program, which is a centralized program developed by the Council of Higher Education but still allowing the universities have autonomy to a certain extent, provides them with less actual teaching practices than theoretical background. In a similar manner, both teacher candidates and in-service teachers should be equipped with necessary knowledge 
and skills through undergraduate courses or in-service trainings about how to respond to the students with special needs as this is found to be another important factor interfering with teachers' classroom management. Lastly, through those channels, it should also be ensured that both parties are provided with adequate opportunities to develop sound knowledge about learner-centered education and the implications of learner-centered classroom management.

This study predominantly delves into the concept of classroom management and establishes a broader structure where metaphors-problems-reasons-practices are considered together. By doing so, this study identifies teachers' beliefs about classroom management in Turkish context. It is believed that these beliefs have a great potential to reflect teachers' actual classroom management practices as beliefs drive the pedagogies and practices of teachers (Pajares, 1992) and thereby, teachers' classroom management approaches are shaped by their belief systems (Combs, 1982). The study also reveals several context-specific factors which might call for classroom management practices that comply with culturally responsive pedagogy and constructivism. Hence, this study sheds light into both pre-service and in-service teacher education in preparing both the teacher candidates in elementary teaching program and the elementary teachers with knowledge and skills needed for more effective classroom management and for more equity practices in the classroom. In addition, the findings provide insights to school administrators in terms of creating a more supportive environment for teachers to manage their classrooms effectively. Finally, this study is important in terms of providing feedback about the match or mismatch between the implications of recent constructivist efforts and classroom management practices in Turkey.

Although the current study offers several implications for policymakers, the teacher preparation program, and in-service trainings, the study is limited to the beliefs of participating elementary teachers about classroom management. On the other hand, teachers' self-reported interview data might be supported with other data sources such as observations to reveal the actual classroom management practices of teachers in classroom settings and to explore how these beliefs play out in those settings.

\section{References}

Akar, H., \& Yildirim, A. (2009). Change in teacher candidates' metaphorical images about classroom management in a social constructivist learning environment. Teaching in Higher Education, 14(4), 401-415.

Akar, H., Tantekin-Erden, F., Tor, D., \& Şahin, İ. T. (2010). Study on teachers' classroom management approaches and experiences. Elementary Education Online, 9(2), 792-806.

Akkok, F., Askar, P., \& Sucuoglu, B. (1995). Safe schools require the contributions of everybody: The picture in Turkey. Thresholds in Education, 21, 29-33. 
Altınel, Z. (2006). Student misbehaviour in EFL classes: Teachers' and students'perspectives (Master's thesis, Cukurova University, Adana, Turkey). Retrieved from https://tez.yok.gov. tr/UlusalTezMerkezi/

Atıc1, M. (2001). Yüksek ve düşük yetkinlik düzeyine sahip öğretmenlerin sınıf yönetimi stratejileri [Classroom management strategies for teachers with higher and lower levels of teaching efficacy]. Educational Administration: Theory and Practice, 7(4), 483-499.

Atici, M. (2007). A small-scale study on student teachers' perceptions of classroom management and methods for dealing with misbehavior. Emotional and Behavioral Difficulties, 12(1), 15-27.

Atıc1, M., \& Merry, R. (2001). Misbehavior in British and Turkish primary classrooms. Pastoral Care in Education, 19(2), 32-39.

$\mathrm{Au}, \mathrm{K}$. H. (1998). Social constructivism and the school literacy learning of students of diverse backgrounds. Journal of Literacy Research, 30(2), 297-319.

Baş, G. (2012). İlköğretim öğrencilerinin yapılandırmacı öğrenme ortamına ilişkin algılarının farklı değişkenler açısından değerlendirilmesi. Journal of Research in Education and Teaching, 1(4), 203-215.

Beasley, L. A. (1996). Autonomy in a constructivist classroom (Doctoral dissertation). Available from ProOuest Dissertations and Theses database. (UMI No. 9632920)

Bogdan, R. C., \& Biklen, S. K. (2007). Qualitative research for education: An introduction to theory and methods. New York, NY: Pearson Education.

Boz, T., \& Yıldırım, A. (2014). 4+4+4 Eğitim sisteminde birinci sınıf öğretmenlerinin karşılaştı̆̆ zorluklar [The challenges faced by the teachers of 1 st grade in the $4+4+4$ education system]. Başkent University Journal of Education, 1(2), 54-65.

Brophy, J. (1986). Classroom management techniques. Education and Urban Society, 18(2), $182-194$.

Cabaroğlu, N. (2012). Prospective EFL teachers' perceptions of classroom management and misbehaviour, Çukurova University Faculty of Education Journal, 41(1), 117-132.

Cabaroğlu, N., \& Altınel, Z. (2010). Misbehaviour in EFL classes: Teachers' and students' perspectives. Çukurova University Journal of Social Sciences Institute, 19(2), 99-119.

Çakmak, M, Kayabaşı, Y., \& Ercan, L. (2008). Teacher candidates' views about classroom management strategies. Hacettepe University Journal of Education, 35, 53-64.

Çandar, H., \& Şahin, A. E. (2013). Yapılandırmacı yaklaşımın sınıf yönetimine etkilerine ilişkin öğretmen görüşleri [Teachers' views about effects of constructivist approach on classroom management]. Hacettepe University Journal of Education, 44, 109-119.

Cerit, Y., Akgün, N., Yıldız, K., \& Soysal, M. R. (2014). Yeni eğitim sisteminin (4+4+4) uygulanmasında yaşanan sorunlar ve çözüm önerileri (Bolu il örneği) [Problems and solutions for the processing of the application of the new schooling system $(4+4+4)($ City of Bolu sample)]. Journal of Educational Sciences Research, 4(1), 59-82.

Combs, A. (1982). A personal approach to teaching: Beliefs that make a difference. Boston, MA: Allyn \& Bacon.

Creswell, J. W. (2007). Qualitative inquiry and research design: Choosing among five approaches. Thousand Oaks, CA: Sage.

Cummins, J. (1986). Empowering minority students: A framework for intervention. Harvard Educational Review, 56, 18-36. 
Cushner, K., McClelland, A., \& Safford, P. (2009). Human diversity in education: An intercultural approach. New York, NY: McGraw Hill.

Demir, S. (2009). Teacher perceptions of classroom management and problematic behaviors in primary schools. Procedia Social and Behavioral Sciences, 1, 584-589.

Denzin, N. K., \& Lincoln, Y. S. (2000). Introduction: Entering the field of qualitative research. In N. K. Denzin \& Y. S. Lincoln (Eds.), Strategies of qualitative inquiry (pp. 1-34). Thousand Oaks, CA: Sage.

Dollard, N., Christensen, L., Colucci, K., \& Epanchin, B. (1996). Constructive classroom management. Focus on Exceptional Children, 29(2), 1-24.

Doyle, W. (1975). Helping beginning teachers manage classrooms. NASSP Bulletin, 59(38), 38-41.

Doyle, W. (1986). Classroom organization and management. In M. C. Wittrock (Ed.), Handbook of research on teaching. A project of the American Educational Research Association (pp. 392-431). New York, NY: MacMillan.

Emmer, E. T., \& Stough, L. M. (2001). Classroom management: A critical part of educational psychology, with implications for teacher education. Educational Psychologist, 36(2), 103-112.

Erdogan, M., \& Kurt, A. (2015). A review of research on classroom management in Turkey. Procedia Social and Behavioral Sciences, 186, 9-14.

Evertson, C. M. (1985). Training teachers in classroom management: An experimental study in secondary school classrooms. The Journal of Educational Research, 79(1), 51-58.

Evertson, C. M. (1989). Improving elementary classroom management: A school-based training program for beginning the year. The Journal of Educational Research, 83(2), 82-90.

Evertson, C. M., \& Neal, K. W. (2006). Looking into learning-centered classrooms implications for classroom management (NEA Working Paper). National Education Association (NEA). Retrieved from http://www.nea.org/assets/docs/HE/mf_cmreport.pdf

Fraenkel, J. R., \& Wallen, N. E. (2006). How to design and evaluate research in education. New York, NY: The McGraw-Hill Companies.

Friedman, I. (2006). Classroom management and teacher stress and burnout. In C. M. Evertson, \& C. S. Weinstein (Eds.), A handbook of classroom management: Research, practice, and contemporary issues (pp. 925-945). Mahwah, NJ: Lawrence Erlbaum Associates.

Garrahy, D. A., Cothran, D. J., \& Kulinna, P. H. (2005). Voices from the trenches: An exploration of teachers' management knowledge. The Journal of Educational Research, 99(1), 56-63.

Garrett, T. (2008). Student-centered and teacher-centered classroom management: A case study of three elementary teachers. Journal of Classroom Interaction, 43(1), 34-47.

Gay, G. (2002). Preparing for culturally responsive teaching. Journal of Teacher Education, 53(2), 106-116.

Gay, G., \& Howard, T. C. (2000). Multicultural teacher education for the 21 st century. The Teacher Educator, 36(1), 1-16.

Gokmenoglu, T., Eret, E., \& Kiraz, E. (2010). Single problem-multiple responses: Lack of congruency toward misbehavior. Procedia Social and Behavioral Sciences, 9, 1602-1606.

Güleç, S., \& Alkış, S. (2004). Öğretmenlerin sınıf ortamında kullandıkları davranış değiştirme stratejileri [The behaviour change strategies used by the teachers in the classroom environment]. Uludağ Üniversitesi Eğitim Fakültesi Dergisi, 17(2), 247-266. 
Güleç, S., \& Balçik, E. G. (2011). Undesirable behaviors elementary school classroom teachers encounter in the classroom and their reasons. Bulgarian Journal of Science and Education Policy (BJSEP), 5(2), 163-177.

Ingersoll, R. M. (2001). Teacher turnover and teacher shortages: An organizational analysis. American Educational Research Journal, 38, 499-534.

Ingersoll, R. M., \& Smith, T. M. (2003). The wrong solution to the teacher shortage. Educational Leadership, 60(8), 30-33.

Kunter, M., Baumert, J., \& Köller, A. (2007). Effective classroom management and the development of subject-related interest. Learning and Instruction, 17(5), 494-509.

Ladson-Billings, G. (1992). Reading between the lines and beyond the pages: A culturally relevant approach to literacy teaching. Theory into Practice, 31(4), 312-320.

Lozano, R., \& Kizilaslan, I. (2013). Approaches to classroom discipline in Turkey and their implications for teacher education. International Journal on New Trends in Education and Their Implications, 4(1), 180-187.

Marshall, C., \& Rossman, G. B. (2006). Designing qualitative research. Thousand Oaks, CA: Sage.

Marzano, R. J., \& Marzano, J. S. (2003). The key to classroom management. Educational Leadership, 61(1), 6-13.

Milner, H. R., \& Tenore, F. B. (2010). Classroom management in diverse classrooms. Urban Education, 45(5), 560-603.

Mundschenk, N. A., Miner, C. A., \& Nastally, B. L. (2011). Effective classroom management: An air traffic control analogy. Intervention in School and Clinic, 47(2), 98-103.

Örücü, D. (2012). Primary school teachers' metaphorical perspectives towards classroom and classroom management: A comparative case study. Elementary Education Online, 11(2), 342-352.

Pajares, M. F. (1992). Teachers' beliefs and educational research: Cleaning up a messy construct. Review of Educational Research, 62(3), 307-332.

Patton, M. Q. (1990). Qualitative evaluation and research methods. Newbury Park, CA: Sage.

Poole, I. R., \& Evertson, C. M. (2013). Elementary classroom management. In J. Hattie, \& E. M. Anderman (Eds.), International guide to student achievement (pp. 188-191). New York, NY: Routledge.

Randolph, C. H., \& Evertson, C. M. (1994). Images of management for learner-centered classrooms. Action in Teacher Education, 16(1), 55-63.

Romi, S., Lewis, R., \& Roache, J. (2013). Classroom management and teachers' coping strategies: Inside classrooms in Australia, China and Israel. Prospects, 43(2), 215-231.

Rosas, C., \& West, M. (2009). Teachers beliefs about classroom management: Pre-service and inservice teachers' beliefs about classroom management. International Journal of Applied Educational Studies, 5(1), 54-61.

Saban, A. (2004). Giriş düzeyindeki sınıf öğretmeni adaylarının “öğretmen” kavramına ilişkin ileri sürdükleri metaforlar [Entry level prospective classroom teachers' metaphors about the concept of "teacher"]. Türk Eğitim Bilimleri Dergisi, 2(2), 131-155.

Sarıtaş, M. (2006). Öğretmen adaylarının değerlendirmelerine göre sınıfta istenmeyen öğrenci davranışlarını değiştirmek ve düzeltmek amacıyla yararlanılan stratejiler [The strategies used in order to change and ameliorate the students' classroom behaviors that are considered undesirable in the evaluations of teacher trainees]. Uludă̆ Üniversitesi Eğitim Fakültesi Dergisi, 19(1), 167-187. 
Schwandt, T. A. (1994). Constructivist, interpretivist approaches to human inquiry. In N. K. Denzin \& Y. S. Lincoln (Eds.), Handbook of qualitative research (pp. 118-137). Thousand Oaks, CA: Sage.

Türnüklü, A., \& Galton, M. (2001). Students' misbehaviours in Turkish and English primary classrooms. Educational Studies, 27(3), 291-305.

Villegas, A. M., \& Lucas, T. (2002). Educating culturally responsive teachers. Albany, NY: State University of New York Press.

Voakley, D. H. (1975). A study of student participation in classroom management to effect an increase in appropriate behavior. The Journal of Educational Research, 69(1), 31-35.

Wang, M. C., Heartel G. T., \& Walberg, H. J. (1993). What helps students learn? Educational Leadership, 51(4), 74-79.

Weinstein, C. S., Tomlinson-Clarke, S., \& Curran, M. (2004). Toward a conception of culturally responsive classroom management. Journal of Teacher Education, 55(1), 25-38.

Weinstein, C. S., Woolfolk, A. E., Dittmeier, L., \& Shanker, U. (1994). Protector or prison guard? Using metaphors and media to explore student teachers' thinking about classroom management. Action in Teacher Education, 16(1), 41-54.

Weinstein, C., Curran, M., \& Tomlinson-Clarke, S. (2003). Culturally responsive classroom management: Awareness into action. Theory into Practice, 42(4), 269-276.

Wubbels, T. (2011). An international perspective on classroom management: What should prospective teachers learn? Teaching Education, 22(2), 113-131.

Yaşar, S. (2008). Classroom management approaches of primary school teachers (Master's thesis, Middle East Technical University, Ankara, Turkey). Retrieved from https://tez.yok. gov.tr/UlusalTezMerkezi/

Yıldırım, A., \& Şimşek, H. (2011). Sosyal bilimlerde nitel araştırma yöntemleri [Qualitative research methods in social sciences]. Ankara, Turkey: Seçkin Yayıncılık. 